\title{
Antitrust and Vertical Integration in "New Economy" Industries with Application to Broadband Access
}

\author{
Bruce M. Owen
}

Received: 4 January 2011 / Accepted: 16 April 2011 / Published online: 3 May 2011

(C) The Author(s) 2011. This article is published with open access at Springerlink.com

\begin{abstract}
Whether the firms that supply Internet hardware and software should face restrictions on the use of their property is an important and controversial policy issue. Advocates of "net neutrality"-including President Obama and the current FCC majority-believe that owners of broadband distribution systems (hardware used to distribute Internet and video services) and producers of certain "must-have" video content should be subject to prophylactic regulation that transcends present-day antitrust law enforcement. In the economic terms that are used in debates on competition policy, the concern is with vertical integration that may give firms both the opportunity (through denial of access or price discrimination) and incentive (increased profit) to restrict competition. This paper's central point is that virtually every production process in the economy is vertically integrated, and economics predicts changes in the extent of vertical integration - that is, changes in the boundaries of the firm-in response to changes in relative prices, technology, or institutions. Both vertical integration and changes in the extent of vertical integration are benign characteristics of efficient, dynamic, competitive markets. While there is no shortage of theoretical models in which vertical integration may be harmful, most such models have restrictive assumptions and ambiguous welfare predictions - even when market power is assumed to be present. Empirical evidence that vertical integration or vertical restraints are harmful is weak, compared to evidence that vertical integration is beneficial—again, even in cases where market power appears to be present. Thus, it is reasonable to conclude that prophylactic regulation is not necessary, and may well reduce welfare. Sound policy is to wait for ex post evidence of harm to justify interventions in specific cases. Net
\end{abstract}

B. M. Owen

Stanford University, Stanford, CA, USA

B. M. Owen $(\varangle)$

Stanford Institute for Economic Policy Research, 366 Galvez Street, Stanford, CA 94305, USA

e-mail: BruceOwen@Stanford.edu 
neutrality, recently enacted by the FCC but subject to judicial review, is an unfortunate idea.

Keywords Access · Antitrust - Broadband - Common carrier · Contracting · Essential facilities - Ex ante regulation - Firm boundaries · Industrial organization . Internet · Net neutrality · New economy · Pin factory · Schumpeter · Vertical integration $\cdot$ Vertical restraints

JEL Classification $\mathrm{K} 20 \cdot \mathrm{K} 21 \cdot \mathrm{K} 23 \cdot \mathrm{L} 10 \cdot \mathrm{L} 11 \cdot \mathrm{L} 14 \cdot \mathrm{L} 22 \cdot \mathrm{L} 23 \cdot \mathrm{L} 24 \cdot \mathrm{L} 38$. $\mathrm{L} 40 \cdot \mathrm{L} 42 \cdot \mathrm{L} 50 \cdot \mathrm{L} 59 \cdot \mathrm{L} 82 \cdot \mathrm{L} 86 \cdot \mathrm{L} 96$

\section{Background}

The antitrust policy revolution that began, to choose a somewhat arbitrary date, with Justice Potter Stewart's dissenting opinion in U.S. v. Von's Grocery (1966), led to the introduction of modern economic analysis in antitrust enforcement. One result was the gradual withdrawal of per se antitrust condemnation of vertical restraints, under Section 1 of the Sherman Act, along with a tendency to treat vertical mergers and acquisitions with less suspicion than had been the case, for example, in Brown Shoe (1962). In Brown Shoe the U.S. Supreme Court condemned as anticompetitive vertical "market foreclosure" the acquisition of a retail chain of shoe stores (with $2 \%$ of the retail market) by a shoe manufacturer with $4 \%$ of shoe production. ${ }^{1}$ Vertical restraints (tying, exclusive dealing, and some forms of price discrimination, among other practices) are sometimes regarded as the contractual counterpart of vertical integration. ${ }^{2}$

In spite of the general trend toward reduced antitrust concern with vertical relationships, ${ }^{3}$ vertical integration has remained a policy problem in certain regulated industries, including communications, transportation, and energy. In this sector certain stages of production have traditionally been seen as "bottlenecks" that are capable of exercising monopoly power and are often subject to price regulation on that account. An incentive to escape the effects of such regulation sometimes has led to vertical integration that would otherwise be privately inefficient, and to anticompetitive behavior that is aimed at suppressing competition in the vertical products. The best-known example is the old Bell System, in which AT\&T defended its long distance and telephone equipment monopolies by denying competitors' access to vertically integrated

\footnotetext{
1 As discussed below, acquiring ownership of a customer or supplier is but one of many forms of vertical integration; others include contractual and customary relationships.

2 It was Chicago School doctrine that most of the potential anticompetitive effects of vertical integration could be achieved through contract, and vice versa. While unilateral vertical "restraints" founded on partial or complete vertical integration often have contractual counterparts, there is no reason to assume that the two phenomena have equivalent private or social costs and benefits.

3 The Supreme Court's approach to vertical restraints has been uneven. In the 1992 Kodak case, for example, the court required an evidentiary showing that customers do not act irrationally when purchasing OEM equipment from OEM suppliers of aftermarket services. Many economists would see this inquiry as unnecessary, at least for commercial buyers. But see Goldfine and Vorrasi (2004), arguing that the lower courts have resisted Kodak.
} 
local telephone networks (Noll and Owen 1994). Similar issues have arisen in electricity transmission and distribution, in rail transport, and in gas and oil pipelines. Antitrust litigation, regulatory reform, and other remedies have mitigated many of these problems, but vertical issues remain in each industry.

More recently, in the Microsoft (2002) antitrust litigation, the U.S. Department of Justice targeted Microsoft's vertical integration of its Windows operating system software with Microsoft Internet Explorer, a web browser, among other alleged abuses. This controversial and complex case was characterized by Microsoft as an unwise attack on its success in developing new technology. This view builds in part on Joseph Schumpeter's (1950) idea that an important form of competition involves innovation-stimulating struggles for market dominance, success at which generates economic rewards that incentivize investment in research and development of successive generations of technology (Evans and Schmalensee 2002; Schmalensee 2000). From a Schumpeterian perspective, Microsoft's monopoly of operating system software, far from being regrettable, was a necessary and temporary stimulant of continued technological progress. ${ }^{4}$

Hahn and Passel (2010) put the point succinctly in a recent online posting:

Regulators need to recognize that in markets driven by rapidly changing technology and huge economies of scale, it's natural for one firm or another to be king of the hill-albeit temporarily. So market share alone is no indicator of anticompetitive behavior or of the difficulty a newcomer with a better idea would have in competing for the business.

The net neutrality debate is not unprecedented. Such debates are endemic to "network industries," which often have or appear to have natural monopoly characteristics. 5 Some courts (but not the Supreme Court Trinko (2004) pp. 410-11) have found in the Sherman Act a right of access to such "essential facilities." The right of access is for the benefit of competitors, not of the essential facility itself (it has none), but of the natural monopolist's upstream or downstream vertical businesses. A right of access for the benefit of customers usually is the result of administrative regulation rather than antitrust intervention. Regulators also offer access rights to competitors. Whether provided by antitrust courts or regulators, a meaningful right of access generally requires some form of price regulation, or at least a non-discrimination rule. Rules or decrees that compel access sometimes take the form of mandates to "interconnect" according to a given technical standard.

The Act to Regulate Commerce, ${ }^{6}$ the first federal common carrier statute, was motivated in large part by a kind of "net neutrality" movement. The "net" consisted of railroads. Shippers of agricultural products, who were resentful of discriminatory railroad rates, provided the political impetus. The original complaint was about a longhaul/short-haul rate differential that was attributable to the exploitation of demand

\footnotetext{
4 Posner (2000) offers a useful antitrust perspective.

5 A natural monopoly satisfies two conditions in a static world: minimum efficient scale must be very large relative to the extent of the market, and there must be insufficient demand to support competition in product space. As discussed below, a natural monopolist may face competition in a dynamic contest from innovators that seek to wrest the monopoly from the incumbent by producing a superior product.

624 Stat. 379 (1887) (creating the Interstate Commerce Commission).
} 
elasticity variation along a rail line. Later, concern focused on discrimination aimed at raising rivals' costs, which was typified by John D. Rockefeller's efforts to disadvantage competitors, who were shipping oil from western Pennsylvania and Ohio to eastern markets. Common carrier regulation of railroads, in the end, promoted rather than discouraged discrimination in rates and tended to restrain competition in both rail shipments and other modes of surface transportation (Kahn 1988; Owen 2007).

Vertical integration remains a potential policy concern, at least when one of the stages of production is thought to have substantial market power. This paper explores current understanding of vertical integration as a possible instance of market failure-perhaps one that is remediable by regulatory or antitrust intervention.

\section{Understanding Vertical Integration: The Pin Factory}

What better way to begin a discussion of the "new economy" than with Adam Smith's pin factory? Smith was fascinated with the process of making pins, especially in a factory where each step was performed by a specialized worker. Smith noted at the very beginning of Book I, Chapter 1 of The Wealth of Nations (1776) that an untrained worker would have difficulty making even a single pin in a day,

[In] the trade of the pin-maker; a workman not educated to this business ... nor acquainted with the use of the machinery employed in it ... could scarce, perhaps, with his utmost industry, make one pin in a day, and certainly could not make twenty.

But ten trained workers could produce much more:

I have seen a small manufactory of this kind where ten men only were employed, and where some of them consequently performed two or three distinct operations. But though they were very poor, and therefore but indifferently accommodated with the necessary machinery, they could, when they exerted themselves, make among them about twelve pounds of pins in a day. There are in a pound upwards of four thousand pins of a middling size. Those ten persons, therefore, could make among them upwards of forty-eight thousand pins in a day.

Smith attributed this increase in productivity to the "division of labor" into specialties:

[The work] is divided into a number of branches, of which the greater part are likewise peculiar trades. One man draws out the wire, another straights it, a third cuts it, a fourth points it, a fifth grinds it at the top for receiving the head; to make the head requires two or three distinct operations; to put it on is a peculiar business, to whiten the pins is another; it is even a trade by itself to put them into the paper; and the important business of making a pin is, in this manner, divided into about eighteen distinct operations, which, in some manufactories, are all performed by distinct hands, though in others the same man will sometimes perform two or three of them. 
Smith also noted that such specialization is possible only if there is sufficient demand to support the level of output required to keep each worker fully employed at a specialized task. That is, specialization and therefore productivity is limited by scale, and scale is limited by the extent of the market. The extent of the market is determined by many factors including transport costs and trade policies. As Stigler (1951) noted, the principle that the division of labor is limited by the extent of the market suggests that large scale production should permit vertical "disintegration," with separate agents that specialize in each stage of production, and relying on the market to deal not only with preceding and succeeding stages of production but also trade between the previously integrated specialties. Disintegration permits the industrial organization of each stage of production to be optimized, for it would be surprising if all stages of production had the same minimum efficient scale. Evidence of industries disintegrating in this way as they grow is not abundant, however. Evidently, vertical integration provides benefits that usually outweigh those of optimizing scale at each stage of production.

Smith's pin-making anecdote contains tokens of other well-known economic phenomena. For example, Smith sees that the relative productivity of the pin makers is enhanced by their own know-how ("education to the business," what today we call human capital), and by machinery, or physical capital. It is also clear that machinery is labor-saving - it enhances the productivity of each hour of labor-and that the machinery need not be used in fixed proportion to labor. ${ }^{7}$

However, Smith makes no mention of the management of production or of the details of the transition between one stage of the production process and the next. Nor does he make mention of a factory owner or a supplier of capital, either for the provision of machinery or to finance work in progress or inventories of raw materials and finished products. ${ }^{8}$

On what terms were the semi-finished products of one stage of pin production transferred to the next? There is nothing in Smith's story to tell us whether each specialized worker or workers sold their intermediate products to the next, in what might be deemed a market, or whether the flow of production was directed by a supervisor or agent acting on behalf of the workers, or on behalf of one or more of the factors of production, or as an agent of the ultimate buyers of pins. Is the manufactory merely a convenient physical space, or does it help define the boundary of an economic unit?

To answer these questions, it may be useful to review what little is known of the manufacture of pins before and during Smith's time. Smith reports on "a small manufactory ... where ten men only were employed," and implies that these workers performed all of the eighteen or so sequential tasks described, from drawing the wire to placing the finished pins into the paper. We know from other sources that pin-making was already a specialized category of metal-working by the time of King Henry VII Tudor. A small Yorkshire town called Sherburn-in-Elmet was described in the 1540s as "a

\footnotetext{
7 Smith's view that the mechanization of production became possible because of the division of labor, however, seems to oversimplify.

8 Everyone involved in the "manufactory," including the skilled workers, bears ex ante risk, because the surplus value that is created by their contributions cannot be realized until later, when the pins are sold. The opportunity value of their capital and labor during the period of production will by then be permanently foregone. Some of this risk can be shifted to others in advance of production as well as through forward transactions or hedges, but these devices create additional claims on the surplus.
} 
market town with many pinners." ${ }^{9}$ Consideration of the limited extent of the medieval market suggests that these pinners were either individual cottagers, each fully integrated, or cottagers who were specialized in one step or another of the manufacturing sequence, or some combination. There were unlikely to have been "many" pinners each consisting of an establishment with 10 or more workers such as Smith observed more than 200 years later. But we do not know whether the cottagers were organized as individual entrepreneurs, selling semi-finished products amongst themselves or as contractors in a "putting out" system that was organized and directed by a merchant, as was common in the British textile industry by the eighteenth century.

"Early in the eighteenth century the pin trade was concentrated in London, Bristol, and Gloucestershire. At this time there were probably a hundred or more pin "manufactories" in the United Kingdom. By the mid-eighteenth century much pin production was located in workhouses and organized as a cottage industry" (Pratten 1980, p. 93). But by about 1800, 40 years after Smith's observation, pin making in Britain was concentrated in fewer than 25 firms. "The factory constituted the dominant mode of production although some manufacturers employed outworkers to perform certain processes" (Dutton and Jones 1983, p. 175). Fixing the head of the pin to the shaft remained the most time-consuming part of the process, accounting for almost half of all manufacturing costs. (Id., p. 176) Women and children were employed to reduce these costs, and factory owners contracted "with overseers of workhouses and superintendents of gaols for the services of inmates." (Id.) Pin manufacturers "often made rapid adjustments to heading capacity through the medium of outworkers." (Id., p. 177)

Descriptions of pin making in the U.S. have not been found, but metal-working factories in nineteenth-century America often used a form of organization called "inside contracting":

Under the system of inside contracting, the management of a firm provided floor space and machinery, supplied raw material and working capital, and arranged for the sale of the finished product. The gap between raw material and finished product, however, was filled not by paid employees ... but by contractors, to whom the production job was delegated. They hired their own employees, supervised the work process, and received a piece rate from the company for completed goods. The income of a contractor consisted of the difference between his wage bill and his sales to the company, plus the day pay he earned as an employee himself. The company's largest single expense was the amount paid to the contractors for finished goods (Buttrick 1952, pp. 205-206; see also Englander 1987).

Both "putting out" and "inside contracting" can be seen either as species of vertical dis-integration, steps toward vertical integration, or static equilibria, depending on the time path of the organization. Differences in the type and degree of integration between firms and over time clearly are much-influenced by path dependence. But it is clear that even in Smith's day some stages of the production of pins took place outside the factory walls, and were not generally brought inside until sometime in the nineteenth century. Even then the pin makers did not mine or refine the metal or own

9 J.S. Lee (2010a, 12-13), citing The Itinerary of John Leland in or about the Years 1535-1543, ed. L. Toulmin Smith, 2nd ed., 5 vols. (London, 1964) vol. IV, 13. 
retail outlets. Despite significant outsourcing, there cannot have been a "market" in the extreme sense of a large number of anonymous agents buying and selling intermediate goods in an auction environment.

It seems that there is no natural or default boundary where the firm ends and markets begin, even for firms in the same business at the same time. History matters, among many other factors. Work done "outside the walls" may be as closely directed and coordinated as any fiat production inside the walls, while important aspects even of management may be delegated by contract. And the same is true inside the walls. Vertical integration is a matter of degree even at a single stage of production. It responds to the historical path of the firm, its economic environment, available legal and political institutions, and social context. A gross change in the extent of vertical (dis)integration may take place either through (dis)investment in production or distribution facilities or by selling/purchasing existing facilities to or from suppliers or customers. But more subtly and probably commonly, a change in the degree of vertical integration takes place whenever the owners of a firm acquire or concede a degree of direct resource control in contractual arrangements with factor or input suppliers or customers.

Not even simple production processes, like pin-making, consume collections of inputs in a single gulp, as it were, to yield immediate marketable outputs. Single-step production processes appear to be very rare. Real world production nearly always involves multiple sequential steps. Because each step or stage-even in a continuous process such as an oil refinery, assembly line, or continuous casting process-changes inputs into outputs, most any common production process can be said to be organized vertically. Thus, "vertically integrated" is an apt description of all firms. Vertical integration in both conventional and professional economic usage is not easily distinguishable from this fundamental characteristic of production.

\section{Vertical Integration Means Many Different Things}

The English language does not sharply distinguish vertical integration as (1) an action that changes the status of a firm from (2) vertical integration as an existing attribute of a firm. To say that "firm A is vertically integrated while otherwise similar firm B is not" means simply that firm A has decided to control a longer list of sequential steps of production. Or it may mean that the degree of direct control of certain steps of production exercised by A exceeds that of B. It cannot mean that firm B is not vertically integrated.

Keeping in mind that every firm is vertically integrated, explanations for observed vertical integration (or its absence) as an organizational characteristic should also apply to changes in the degree of integration. Indeed, these explanations often work both ways, identifying a dimension along which direct control of production decisions varies in effectiveness relative to control by others (suppliers, buyers, or agents with various legal and economic connections to the firm). It seems clear that the same factors should apply within a firm as well as within markets, leaving both firms and markets less well-defined or distinct than is customarily assumed.

Thus it seems that being vertically integrated is the default status of organizations or firms, and that the interesting questions concern the degree and form of integration: 
what degree of discretion over production decisions is allocated to the suppliers of inputs, factors of production, or distributors, and what are the causes of changes in that degree.

Holmstrom and Roberts (1998, pp. 83-84) describe an interesting practice in the steel minimill industry. Minimills produce steel from scrap metal rather than from iron ore and coke. Efficient steel production requires that the scrap and other material inputs with which the furnace is "charged" have a very specific composition in order to produce steel with desired characteristics. The exact specification of the appropriate charge is calculated by highly specialized experts. One producer delegates responsibility not just control over the design of the charge, but even over the steps necessary to assemble the charge itself and to insert the charge into the furnace. This is the very heart of the steel-making business. The minimill in this case outsources the service of supervising and even performing a crucial production step inside its own factory.

\section{Firm Boundaries}

Vertical integration is usually defined in terms of the boundary between the firm and the market (Coase 1937; Klein et al. 1978). Smith's pin factory presumably was a firm, most likely a partnership or sole proprietorship, one in which the supplier of equity capital claimed any residual surplus and therefore took responsibility for coordination of the team effort. Firms are usually considered to allocate internal resources on the delegated personal authority that is exercised by a hierarchy of managers. As suggested above, however, at least some of the coordination may be accomplished by marketlike devices, such as relational contracts, incentive pay, profit sharing, out-sourcing, and inside contracting. In other words, firms can use markets to allocate resources internally, just as markets can be subjected by regulators to external fiat controls.

The powerful idea of incomplete contracts highlights the partially conflicting incentives of the parties to both market and intra-firm transactions. (Transaction is probably not the best word - what happens between steps in a production process is a partial shift in sovereignty over specified resources.) We traditionally assume that each party wants to maximize its own surplus with respect to the variables that it controls, but only in a timeless and otherwise abstract world is this incentive compatible with overall welfare maximization. Internalization has the potential to reduce the costs of incentive incompatibility, including the opportunity cost of forgone transactions.

The Coasian firm is defined by a collection of production steps for which external market transaction costs exceed internal production costs. Williamson $(1975,1985$, 1991, 1996) unpacked Coase's insight by focusing on the factors that determine the boundaries between the firm and the market, especially the difficulties of designing incentive-compatible contracts and the hurdles that are created by transactional and information costs.

Both internal fiat-guided production and the full range of market transactions can be viewed as describing continua of agent relationships. Relationships within the factory are governed by hierarchical and decentralized decision loci as well as, on occasion, formal written contracts, social conventions, complex committee structures, and interpersonal relationships. Gibbons (2010) describes the extensive literature on 
the economics of internal organization of firms. Relationships between firms and external agents frequently are governed by informal or "relational" contracts that are heavily influenced by the parties' mutual interest in continuing cooperation. The same is true inside the firm, among employees, between managers and employees, and of course between the "owners"—-another heterogeneous lot—and the managers.

Gaps in the spectrum of feasible agent relations in principle can lead to inefficiency. The existence of gaps is largely traceable to the institutional legal environment that affects rights: specifically, residual claims in corporate law, incomplete property rights, and inefficient contract and agency law. Broadly speaking, efficient organizational arrangements are facilitated when access to legal enforcement is swift and inexpensive and "what courts will do" in the event of disputes (absent voluntary agreements to the contrary) is predictable (Holmes 1897). But it is quite possible that there are relevant legal gaps (restrictions on the freedom to exercise and alienate control over resources) both within the firm and in the market. ${ }^{10}$ For example, the attributes of corporations, partnerships, and other legal and tax definitions of the firm may be inefficiently discrete and lumpy.

Coasian fiat organizations exist in order to conduct activities at which markets would be less efficient, and markets allocate resources where centralized internal allocation would be less efficient. One implication is that if firms and markets are permitted to compete with each other for control of resources, the economy as a whole will produce the same or more output with given resources than would sole reliance on either allocation method. ${ }^{11}$

Productive activity operates purposefully on objects, ideas, or people to increase their value, creating a surplus that can be divided among the participants as an inducement to join in the process. Participants include the owners of factors of production, as well as suppliers of inputs including such services as risk-bearing and management, middlemen, and consumers of outputs. The relationships among the participants can take many forms: anonymous counterparties in spot transactions, long-or short-term formal or relational contracts, employer-employee, and combinations or intermediate versions of these connections. Even the simplest process usually can be meaningfully decomposed into sequential or simultaneous actions that are undertaken by separate agents. Involving multiple agents requires cooperation, motivated by an increase in surplus compared to unilateral production. The potential for added surplus is in the most general sense a product of technology or know-how, such as economies of specialization from the division of labor or economies of scale from the concentration of production at a particular point in space and time.

An increase in surplus is no inducement to cooperation unless each agent expects to claim a share that exceeds her opportunity cost. But expectations are affected by

\footnotetext{
10 I have in mind a theoretically efficient and continuous multidimensional frontier of attributes that are available to organize relationships between agents, both intra- 'firm" and otherwise. In such a case the dividing line between firms and markets is arbitrary. Discontinuities may arise from legal dividing lines.

11 A firm may exist (or integrate) not because it engages in significant physical transformation of inputs into outputs, but because it can perform functions internally that are more costly if undertaken through the marketplace. For example, a firm can engage in "black market" transactions that would be unlawful or detectable if conducted at arm's length, or it can internalize a local externality in order to align incentives. Internal transfers across national boundaries, for example, may be motivated by tax avoidance.
} 
the knowledge that post-production incentives differ from pre-production incentives. Cooperation necessitates enforceable ex ante agreement or an expectation of fair treatment. Institutional mechanisms, social connections and conventions, ${ }^{12}$ reputation effects, emotional attachments, information and monitoring costs, and other factors determine the efficacy of pre-production agreements. Agreements and expectations of ex post performance can be enforced in many ways-for example, by courts, by the threat of violence, or by reputational concerns. Expensive enforcement methods cut into the surplus; hence, efficiency requires cost minimization of public as well as privately-supplied enforcement.

Work on the nature of the distinction or "boundary" between the firm and the market has focused on the efficacy of various methods that are used to achieve compatibility between the incentives that face individuals and the incentives that face the parties as a group. It turns out that the boundary between firms and markets is neither sharp nor static. "The market" is a best thought of as a set of multidimensional institutional relationships that are only partially distinct (i.e., distinct only in a subset of the relevant dimensions) from the set of relationships within the firm. For example, the legal organization of the firm itself is highly variable, with many different possible arrangements of the obligations of "owners" to each other and to third parties. Similar variations exist in the relationships between neighboring agents in a sequential production process, sometimes yielding dysfunctions that are the subject of an extensive literature (Gibbons 2010; Robinson 2008). Likewise, the textbook spot market is not a realistic picture of the range of contractual and other relationships between otherwise unrelated buyers and sellers. Indeed, even highly organized transactions in "homogeneous" commodities such as wheat generally are contractual through third parties rather than traded anonymously.

Near the boundaries between "firms" and "markets," or more usefully, between different ways of defining agent relationships in conducting transactions, relatively small changes in information costs, technologies, or institutions can tip the relationships from market-like to firm/fiat-like or vice versa. Of course, the one-time costs of making such a change matter, as do expectations about the permanence of the conditions that support a shift. Changes in the extent of vertical integration-even minor alterations in the terms of supply or distribution contracts-usually involve one-time costs, and the potential benefits of the change must exceed these costs.

I have portrayed the production process in the familiar paradigm of a factoryperhaps a pin factory-with a step-by-step sequential manufacturing process, and have focused on what happens, or may happen, between steps. Of course the real world is usually more complicated than a pin factory, with multiple parallel production "lines," many potential branches and loops, and often a need for decisionmaking at each step to determine which of many potential or alternative next steps should be taken. Thinking about the process that produces health care services to a particular patient in a hospital provides an example of this complexity. Not surpris-

\footnotetext{
$\overline{12 \text { Jackson and Schneider (2010) }}$ demonstrate empirically that strong agent social connections reduce moral hazard problems in the presence of incomplete contracts. For examinations of the behavioral perspective, see Diamond and Vartiainen (2007).
} 
ingly, hospitals use out-sourcing, inside contracting, market transactions and variations on these relationships all at once in an environment where changing technology and external institutional evolution make constant adjustments in the relationships necessary.

In sum, hierarchical organizations have limitations and imperfections that lead to the use of markets and prices. Markets have limitations and imperfections that lead to the use of hierarchical organizations. Competition among these varied ways of conducting productive activity probably helps improve the efficiency of the economy as a whole. The most useful lesson from this discussion is that agent relationships that are defined in legal terms are not necessarily of economic significance. There is not a clear economic distinction between the firm and the market, even when the legal distinction seems quite sharp. A focus on vertical integration can be a misleading attempt to cram a multi-dimensional space into a single index. The firm can be considered as a bucket of contracts among counterparties, with each having at least one foot outside the organization.

\section{The Literature on Vertical Integration}

There are many summaries of the modern literature on vertical integration, of which one of the most complete and accessible is Joskow (2005, pp. 319-326). Joskow identifies incomplete contracts as the key to a spectrum of potential market failures that can be remedied by vertical (dis)integration, as the following outline suggests:

Incomplete contracts (as manifested by or together with one or more of the following):

Moral hazard (incentive compatibility, free riding, shirking)

Asset specificity (lock-in, hold-up, opportunism, incl. human capital)

Risk and uncertainty (e.g., supply insecurity, partial integration)

Differential transactions costs ${ }^{13}$

Differential information costs (asymmetric information, non-observable attributes)

Differential enforcement costs

Differential monitoring costs

External effects (incomplete property rights)

Differential optimal scales among stages of production

Market power

Double marginalization

Price discrimination (partial integration)

Exclusion (raising rivals' costs)

To Joskow's list, one should add additional conditions that possibly explain the degree of vertical integration observed:

Legal constraints

Law and tax avoidance (e.g., contract provisions or property claims that courts will not enforce; see also Zanarone (2009))

$\overline{13}$ That is, "differential" between fiat-like, contract-like, or market-like. 
Behavioral (e.g., separations or delegations of decision-making authority to mitigate cognitive bias (Feng and Hendrikse 2010) or organizational arrangements to minimize ex post opportunism ${ }^{14}$ )

Networks, two-sided markets, "platforms" (R.S. Lee (2010b))

An incomplete contract is one that fails to specify what happens in the event of one or more possible contingencies. Of course, all contracts are incomplete because most contingencies are so remote or inconsequential that they are not worth negotiating. The theoretical remedy is a law of contract construction that requires judges to interpret the contract in the way that the parties would have done ex ante, or at least to have clearly predictable default rules for allocating risks. An incomplete contract has economic significance chiefly when it leads the parties to fail to maximize joint gains; the incompleteness is not a failure to enumerate exhaustively all contingencies but rather a failure to harmonize the parties' incentives. Of course this may not be possible in circumstances that would require unlawful (or otherwise unenforceable) constraints on the parties' ex post behavior. There is no particular reason to believe that economic relationships within a "firm" are more or less subject to imperfections of completeness than are economic relationships outside the firm.

Market-power-motivated vertical integration or dis-integration obviously is of greatest interest from an antitrust perspective. This category consists of vertical integration that gives rise to, or more fully exploits, market power. There are essentially three points about these models: First, vertical restraints that appear to be associated with vertical integration can often be achieved through contracts instead, although not necessarily as effectively, and with different antitrust risks. Second, the welfare effects of market-power-motivated vertical integration are often positive or ambiguous. The best-known examples are the elimination of double marginalization and partial integration to support price discrimination.

Riordan (2008, p. 48) provides a review of the literature on the competitive effects of vertical integration. Like many other economists, Riordan points out that vertical integration is generally a welfare-enhancing response to conditions that would otherwise be characterized as market failures. "A general presumption that vertical integration is pro-competitive is warranted by a substantial economics literature identifying efficiency benefits of vertical integration, including empirical studies demonstrating positive effects of vertical integration in various industries."

There is a "post-Chicago" literature that seeks to identify conditions under which vertical integration may have adverse welfare effects even in the absence of regulation. For a sampling, see Ordover et al. (1990); Riordan and Salop (1995); Salop and Scheffman (1987); Salinger (1988); Schmalensee and Willig (1989), and the summary by Yoo (2002, p. 171). These largely game-theoretic models tend to be built on assumptions, and to produce results, that are very difficult to apply to real-world cases (Cooper et al. 2005).

Third, the empirical studies (which tend to be biased in favor of finding adverse effects of vertical integration) often find the opposite results from those that are

\footnotetext{
14 Hart and Holmstrom (2010) explore these issues in the context of the property rights literature on firm boundaries.
} 
emphasized in the post-Chicago literature. Lafontaine and Slade (2007, 2008a,b) (hereafter L\&S) review a substantial theoretical and empirical literature on the determinants of firm boundaries. Summarizing, L\&S conclude- $[\mathrm{O}]$ verall a fairly clear empirical picture emerges. The data appear to be telling us that efficiency considerations overwhelm anticompetitive motives in most contexts. Furthermore, even when we limit attention to natural monopolies or tight oligopolies, the evidence of anticompetitive harm is not strong. (L\&S at 677) ... As to what the data reveal in relation to public policy, ... [w]e are ... somewhat surprised at what the weight of the evidence is telling us. It says that, under most circumstances, profit maximizing vertical-integration decisions are efficient, not just from the firms' but also from the consumers' points of view. Although there are isolated studies that contradict this claim, the vast majority support it. Moreover, even in industries that are highly concentrated so that horizontal considerations assume substantial importance, the net effect of vertical integration appears to be positive in many instances. We therefore conclude that, faced with a vertical arrangement, the burden of evidence should be placed on competition authorities to demonstrate that that arrangement is harmful before the practice is attacked. Furthermore, we have found clear evidence that restrictions on vertical integration that are imposed, often by local authorities, on owners of retail networks are usually detrimental to consumers. Given the weight of the evidence, it behooves government agencies to reconsider the validity of such restrictions (Lafontaine and Slade (2007, p. 680)).

Finally, regulated firms may resort to inefficient vertical integration to escape regulatory constraint Bustos and Galetovic (2009). In other words, regulation itself can have the unintended consequence of damaging consumer welfare. ${ }^{15}$ The monopolization case brought against the old Bell Telephone System by the U.S. Department of Justice in 1974 provides a useful but apparently rare example. ${ }^{16}$

The Bell System defended its vertical and horizontal integration by claiming the existence of economies of scale and scope, as well as economies of vertical integration. In AT\&T's view, natural monopoly attributes justified exclusionary tactics to discourage inefficient entry. The government argued that vertical integration was motivated not by economies but by a desire to escape regulatory constraints on its profits. The local operating companies had no incentive to exclude AT\&T competitors aside from their vicarious interest in the prosperity of their only stockholder (Noll and Owen 1994). After the breakup, competition flourished and prices fell precipitously at all three stages: long distance service, equipment manufacture, and local services. This evidence is consistent with the view that vertical integration in the old Bell System was the cause of considerable welfare loss. But generalizing from this example is difficult, in part because the role of regulators in the AT\&T case was unique. For many years the FCC endorsed and facilitated the maintenance of the Bell System monopoly.

\footnotetext{
15 Throughout this paper I use this term to mean aggregate economic well-being, putting aside distributional issues.

16 The case ended with a settlement described in United States v. AT\&T (Modified Final Judgment), 552 F. Supp. 131 (D.D.C. 1982), aff'd sub nom. Maryland v. United States, 460 U.S. 1001 (1983). Aside from the Bell System, other historical examples of vertical integration to escape regulatory constraints include oil pipelines, electric power transmission, and railroads.
} 


\section{What is a "New Economy" Industry?}

The term new economy (or sometimes "high tech") is used typically to refer to businesses whose technology of production is (or whose products are) changing. The semiconductor industry is high tech because both its production processes and product characteristics are improving at a rapid rate. The same is true in "bio-tech," telecommunications, aerospace, and instrumentation industries, among others. Clearly there are other ways to define "high tech." The OECD (1993), for example, uses expenditures on R\&D as a percentage of sales to distinguish high tech industries from others. In contrast, the United States Antitrust Modernization Commission (2007, p. 31) opined that "the new economy includes those industries in which innovation, intellectual property, and technological change are central features." But the term cannot be defined for present purposes without reference to the context in which it will be used, and the context here is vertical integration and antitrust policy.

Microsoft's use of the Schumpeterian defense in its dispute with the U.S. Department of Justice was intended to suggest that there is something different about the "high tech" industrial category, to which Microsoft assigned itself, that calls for a relaxation of the usual antitrust policies and standards. Schumpeter's argument was that the potential profits that are associated with dominating a market are a useful inducement to the expenditure of resources on a continuing flow of risky investments in new production technologies or products.

Schumpeter and his followers had in mind an industry that is characterized by a continuing game in which process or product innovation is a key dimension of competition, requiring significant investment and risk. Competition produces a succession of superior technologies, each of which is the exclusive property of a single firm, one of which temporarily dominates the market. Static price competition plays at best a minor role, although the interaction of pricing, any scale economies, and adoption lags might change this. At any moment in time, there will likely be a dominant firm: one with a very large market share that is attributable to technical success. But the dominant firm's (or at least the current technology's) success is transient. ${ }^{17}$ There is avid competition to discover and exploit the next new technology. Over time, prices are falling or, equivalently, product quality is improving. Driving this process is the desire to capture quasi-rents during the period of market dominance. This induces competitors to invest in innovation, or in the creation of intellectual property, and one of these investments eventually succeeds in displacing the incumbent market leader or technology.

The implicit Schumpeterian critique of antitrust policy is that efforts to deter or terminate dominance reduce or eliminate the incentive to innovate. In consequence, while prices may be kept "competitive," they do not fall over time as rapidly as would the prices of "successive" monopolists. Prices that are determined by a static competitive process can be characterized as "competitive prices." But such prices can be higher than monopoly prices if the monopolist has lower costs (or better products) than the

\footnotetext{
$\overline{17}$ A recent contribution by Acemoglu and Cao (2010) focuses on a model of incumbent versus new entrant innovation in which the welfare measure is growth of total factor productivity. In their model, the incumbent contributes as much as $75 \%$ of the growth in total factor productivity.
} 
competing firms. Of course the monopolist's costs would be lower still. Schumpeterian dynamic competition based on technological progress can be an efficient second-best process if the rate of technical progress under successive monopoly is sufficiently greater than under static competition.

From a consumer welfare point of view, of course, this makes sense if the benefits of innovation outweigh the losses from supra-competitive pricing. Along the Schumpeterian policy path prices are falling but nevertheless are greater than costs, creating static deadweight losses as well as rents that serve as incentives to R\&D. In the alternative world, prices are equal to cost but not falling — or not falling as fast (Baker 2007 provides a fuller analysis). In a long-run context, of course, technological progress is far more important than is static pricing efficiency in improving consumer welfare.

Present but not fully explicit in this analysis is the assumption that only the rewards of monopoly are sufficient to induce firms to bear the risks of invention and innovation. There is no reason why this should be so as a general matter, though of course it might be so in particular cases. ${ }^{18}$ And even if it is so in particular cases, why are intellectual property (IP) rights not sufficient to supply the necessary incentives? Again, IP may be sufficient in some cases and not in others, and perhaps be excessive in yet a third category. In short, both IP and antitrust should be industry-specific. Antitrust prosecutorial policy already is highly industry-specific, although private antitrust law generally is less so. IP policy varies hardly at all by industry, except where Congress has created special treatments audio-visual content, as it has for pharmaceuticals, music, and some broadcast and Internet-related.

The key factors that distinguish industries appear to be the degree of risk that is associated with varying levels of $R \& D$ and the extent of scale economies in $R \& D$ effort. Are incentives to invest in R\&D suboptimal in structurally competitive industries? This has been an enduring issue in economics, with few clear theoretical or empirical insights. Likely the answer differs by industry, and empirical tests of general theoretical models are hampered by the absence of counterfactual observations. Yet it remains an empirical question as to which policy yields greater welfare. ${ }^{19}$

The applicability of the Schumpeterian view of dynamic competition to antitrust policy may not depend especially, or at all, on the presence of rapid technological change. According to Sutton (1991) and Schmalensee (1992), Schumpeterian dynamic competition is based on the existence of "endogenous sunk costs, in which spending on advertising, research, or product design and development is an important aspect of competition," (Evans and Schmalensee 2002, footnote. 1). But this describes much of the economy, which consists in large part of imperfectly competitive and

\footnotetext{
18 Kenneth Arrow (1962) long ago emphasized the importance of competition in producing technological progress.

19 The post-Schumpeter economics literature on the relationships between technological innovation and market structure appears to support few generalizations. There are now many industry case studies of the influence of market structure on innovation. Earlier more general takes on the issue appear in Fellner (1951) and Swan (1970). Teece (1992) explores the role in innovation of cooperation among firms with ambiguous boundaries. More recently, Acemoglu and Cao (2010) review the modern theoretical models, and Burt and Lemley (2009) offer a proposed taxonomy of Schumpeterian and non-Schumpeterian industries that is based on modern empirical work.
} 
oligopolistic industries in which "spending on advertising, research, or product design and development is an important aspect of competition."

According to Evans and Schmalensee (2002, pp. 7-11) the key characteristic of "new economy" dynamically competitive industries are low-marginal costs/high fixed costs, labor and human capital intensity, and network and system effects. Varian (2001) claims that "The term "New Economy" refers to a golden, or at least gilded, age in the late 1990s that was driven by optimism about the financial prospects for information technology (IT)." Varian more specifically writes that

[V]arious economic phenomenon ... important in high-technology industries, such as personalization of products and pricing, versioning, bundling, switching costs, lock-in, economics of scale, network effects, complements and computer-mediated contracts ... tend to point towards higher industry concentration [ratios] for technology-intensive industries. (Id.)

Varian's list today probably would include "two-sided markets" and "platforms." (R.S. Lee 2010b).

Posner (2000, pp. 1-2) uses “the term 'new economy' to denote three distinct though related industries:" (1) the manufacture of computer software; (2) Internet-based businesses (Internet access providers, Internet service providers, Internet content providers); and (3) communications services and equipment designed to support the first two industries.

It does not appear that the Schumpeterian model relies especially on the presence of rapid technical change of the sort that is associated with the conventional picture of high tech industries today. The policy issues that are associated with vertical integration are not limited to high tech industries, although it is true that risks and uncertainties that are associated with rapid growth in such industries may make vertical integration and especially changes in the extent of vertical integration more likely.

If we accept any of these somewhat divergent definitions of the "new economy," is there a basis for applying different antitrust and/or regulatory standards? The standards that matter for this purpose establish the thresholds at which intervention by government is believed likely to produce significant social benefits, net of the expected value of error costs. Antitrust standards are set by courts and by prosecutorial policies. The most formal and extensive of these is the U.S. Department of Justice and Federal Trade Commission Horizontal Merger Guidelines (rev. 2010), which establishes intervention thresholds that are based on a complex analysis of market structure and other factors that are thought to affect the likelihood that a given merger would reduce consumer welfare. Antitrust standards are of general applicability but their complexity and multi-dimensionality tailors them, in effect, to particular market characteristics. The result probably is similar to having separate guidelines for each industry.

One problem with the Horizontal Merger Guidelines is that they focus on the likely welfare effect of the specific transaction under review, while the arguably much more important economic effect of decisions to intervene or not is on deterrence of both welfare-reducing and welfare-enhancing future transactions. Such deterrence is effected by the "signals" that enforcement actions send about how prosecutors and courts will deal with similar future cases. The signals are incorporated in expectations and risk assessment by potential merger partners and their financiers. In "new 
economy" industries external sources of capital investment tend to be more important than are internal sources, and business risks are perceived to be high and command compensating high expected returns. If capital markets perceive a high risk of antitrust intervention that is attendant to business success, investment will be reduced.

A similar effect operates with respect to the risk of government monopolization litigation. The standards for monopolization under Section 2 of the Sherman Act are much less specific than are the Horizontal Merger Guidelines, making the effect of prosecutorial "smoke signals" that much more important. The Schumpeterian perspective suggests that increases in the perceived risk of enjoying monopoly rents will discourage innovation.

The United States Antitrust Modernization Commission (2007, p. 32) concluded that:

1. There is no need to revise the antitrust laws to apply different rules to industries in which innovation, intellectual property, and technological change are central features.

2. In industries in which innovation, intellectual property, and technological change are central features, just as in other industries, antitrust enforcers should carefully consider market dynamics in assessing competitive effects and should ensure proper attention to economic and other characteristics of particular industries that may, depending on the facts at issue, have an important bearing on a valid antitrust analysis.

This seems to ignore the costs and benefits of deterrence as a (or perhaps the) central feature of intervention policy, and is to that extent clearly mistaken.

Another issue that arises in Schumpeterian competition is how to treat actions by the incumbent market leader to "bias" the next round of technological progress, perhaps by forestalling or delaying entry by firms in possession of promising new production methods or products. For example, at the time that the Bell System was disintegrated it was necessary to decide whether wireless telephone licenses (only two of which were then allocated to any one geographic area) should be awarded to the local monopoly telephone companies or instead to the competitive long distance firm that would become the new AT\&T. It was decided to give these licenses to the monopoly local exchanges, even though wireless telephony was then the chief means of instituting prospective local telephone competition.

Incumbent dominant Schumpeterian firms may seek to keep out competitors by acquiring and warehousing intellectual property or by erecting other sorts of entry barriers. Such behavior is traditionally within the scope of private and government actions that enforce the "attempt to monopolize" provisions of the Sherman Act Sec. 2. A particular form of such behavior is the acquisition of potential rivals who are in possession of promising new technologies or product designs. For example, Google has recently acquired small online advertising- or video-related firms such as YouTube, DoubleClick, AdMob, and ITA. These acquisitions are subject to review under the standards of the Clayton Act Sec. 7, which are much stricter than Sherman Sec. 2. But of course non-Schumpeterian dominant firms have the same or similar incentives. There is no obvious reason why "new economy" firms require a different set of either 
Clayton Sec. 7 or Sherman Sec. 2 attempt standards than do other firms that compete mainly the basis of price or product quality. ${ }^{20}$

Regulatory standards are set both by (often vague or poorly drafted) statutes and by regulatory agencies with jurisdiction over specific industries. For example, the U.S. Federal Communications Commission (FCC) in the last decade chose to assign Internet-related businesses to "information services," a regulatory category that was established in 1966 for the purpose of differentiating non-regulated services from regulated telephone services. Information services are not subject to common carrier access regulation or price regulation. The FCC thought that information services could or should be provided on a competitive basis by anyone, including regulated monopoly firms if they operated with certain safeguards, such as separate accounting systems. In this case the intervention standard was whether or not the business was or could be made competitive, not whether it was or could be supplied by a monopolist through vertical integration.

The FCC's net neutrality initiative would reverse the earlier policy. ${ }^{21}$ The same consideration of effects on expectations applies to the proposed reversal of a policy that was set only recently. The signal that is sent to the investment community is that nothing done by a regulator can be taken as a given. A reversal of political fortunes may also reverse substantive policies upon the assumed continuance of which investments have been justified. The practical effect is the same as an increase in business risks, and the result is to reduce investment in the affected industry.

Strong policy conclusions cannot be based on these observations without making assumptions about the efficiency of investment levels in the absence of the possibility of government intervention. If we think that markets that operate without uncertainty concerning government action would be approximately efficient, then introducing such uncertainty would reduce investment and welfare. The remedy would be either "new economy"-specific intervention standards or general standards that are sufficiently flexible to permit accurate forecasting of interventions in specific industries or transactions.

\section{Policy Analysis}

Whether the firms that supply Internet hardware and software should face restrictions on the use of their property is an important and controversial policy issue: an application of the "intervention policy" issues discussed above. Advocates of "net

\footnotetext{
20 Burt and Lemley (2009) (see also Lemley 2010) would say that the proper distinction is between industries where some degree of market power is necessary to induce technical progress and those where it is not.

${ }^{21}$ See the FCC's Open Internet Order, (2010). According to the FCC, the rules are: (1) all ISPs must disclose their network management practices and the terms and conditions of service; (2) fixed (i.e., wired) providers, such as cable modem ISPs, may not block any lawful Internet content, applications, services, or devices; for their part, wireless mobile providers (i.e., mobile telephone companies that provide broadband service) may not block Internet content or applications that compete with their own telephony services; and (3) fixed (as opposed to wireless mobile) providers may not unreasonably discriminate in transmitting lawful network traffic. The rules thus apply to the interstate communications services of both fixed and mobile ISPs, albeit somewhat differently.
} 
neutrality" - including President Obama and the current FCC majority (Nocera 2010) - believe that owners of broadband distribution systems (hardware that is used to distribute Internet and video services) and producers of certain "must-have" video content should be subject to prophylactic regulation that transcends present-day antitrust law enforcement. Their objective is to protect the free and open culture of the Internet from efforts to foreclose or limit competition in the provision of content, including online video services, which they see as potential competition to older video distribution methods.

In the economic terms that are used in debates on competition policy, the concern is with vertical integration that may give firms both the opportunity (through denial of access or price discrimination) and incentive (increased profit) to restrict competition. Antitrust laws already provide tools to deal with such concerns (as was illustrated by the antitrust breakup of the old Bell System), which are designed to remedy precisely these offenses. But, except in merger cases, antitrust usually is an ex post remedy. Do "new economy" industries have characteristics that make vertical integration so potentially pernicious that ex ante regulation is justified? Or do "new economy" industries on the contrary exhibit features that make ex ante regulation futile or even dangerous?

The air in Washington is alive with contending voices that are taking sides on these issues. As indicated above, the terms "vertical integration" and "new economy" turn out to be surprisingly elusive concepts. Further, the theoretical and empirical work on vertical integration as it relates to antitrust policy, especially in "new economy" industries does not support the visceral assumptions of those who fear vertical integration.

Virtually every production process in the economy is vertically integrated, and economics predicts changes in the extent of vertical integration - that is, changes in the details of the allocation of sovereignty over intermediate products and productionin response to changes in relative prices, technology, or institutions. Both vertical integration and changes in the extent of vertical integration are, in general, benign characteristics of efficient, dynamic, competitive markets.

While there is no shortage of theoretical models in which vertical integration may be harmful, most such models have restrictive assumptions and ambiguous welfare predictions - even when market power is assumed to be present. Empirical evidence that vertical integration or vertical restraints are harmful is weak, compared to evidence that vertical integration is beneficial-again, even in cases where market power appears to be present. Thus, it is reasonable to conclude that prophylactic regulation is not necessary, and may well reduce welfare by deterring efficient investments. Sound policy is to wait for ex post evidence of harm to justify interventions in specific cases. The conditions that would trigger such intervention should be as concrete and specific as possible, in order to reduce perceived investment risk.

All firms exhibit some degree of vertical integration, and constant changes in this degree are a predictable side effect of a dynamic, competitive economy. Most vertical (dis)integration is by nature welfare-enhancing simply because vertical (dis)integration is a common remedy for market failure or disequilibrium, as well as a natural outcome of competition among organizational forms for economic advantage. Thus, there is no basis for an a priori assumption that vertical integration is welfare-reducing.

There is a limited set of circumstances in which an increase in vertical integration is more likely (though not necessarily likely) to be welfare-reducing. These include 
the presence of market power and regulation, but market power and regulation are not sufficient conditions for adverse welfare effects.

If we observe a firm with significant market power that is increasing its degree of vertical integration, should public officials react by imposing regulatory safeguards such as access obligations and price controls? Clearly they will be under political pressure to do so from competitors of the integrating firm. But as we have seen, both theory and evidence suggest that the effect of such integration is often benign. Intervention thus risks not just slowing or stopping a movement toward increased efficiency, but of creating unintended adverse effects. Adverse effects from a change in the organization of agent relations seem sufficiently rare that ex ante intervention is unwise, particularly in light of the great difficulty of repealing regulatory interventions. As an empirical matter, "[C]onsumers are often worse off when governments require vertical separation in markets where firms would have chosen otherwise" (Lafontaine and Slade (2007, p. 663)).

Finally, the heightened antitrust scrutiny that is accorded to horizontal mergers in general is likely unwarranted in the case of vertical mergers. The law distinguishes "organic" (internal) integration from integration by acquisition. A merger or acquisition may come within the scope of Section 7 of the Clayton Act, whereas internal changes are reached, if at all, only by Section 2 of the Sherman Act. This legal distinction involves issues of jurisdiction as well as a sharp difference in standards. From an economic point of view there is no good reason for the distinction. The usual rationalization is that "organic" expansion of the scope of a firm is less likely to be anticompetitive than expansion through merger or acquisition, but the basis for this assessment has never been clear. After all, if the current status of an organization is made inefficient due to changes in its economic environment, it is best to move as rapidly as possible to the new, more efficient organizational form. To the extent that vertical restraints achieved through contract can accomplish the same exclusionary effects as vertical integration, whether from acquisition or internal growth (L\&S 667), the case for ex ante regulation is further weakened.

At this writing the most recent prominent antitrust controversy involving vertical integration was the acquisition of NBCU, chiefly a producer of video entertainment, by Comcast, chiefly a provider of local broadband video and Internet transmission services. The acquisition was subject to review by the Department of Justice as well as the FCC. The Commission, more generally, has a policy of opposition to vertical integration between content suppliers and distributors such as cable systems and has even designated certain cable channels (e.g., regional sports networks, or RSNs) as the equivalent of "essential facilities" for competing video distributors. The Commission's policy relies on statutory authority in the Cable Act of 1992 and in its ability to impose "conditions" on the approval of license transfers incidental to mergers and acquisitions in the industry. In the Adelphia case (2006), for example, the assignment to Comcast Cable and Time Warner Cable of licenses that were owned by the estate of bankrupt Adelphia Cable was required in order to facilitate the sale of the associated Adelphia cable systems. The FCC focused on the possibility that video distribution rights that were owned by Comcast or Time-Warner for a given territory could be profitably withheld from competing distributors, such as DirecTV, if those companies also controlled local cable systems in the territory. The FCC thought that this incentive would be 
enhanced if the Adelphia transaction increased the percentage of potential subscribers in a territory that patronized Comcast or Time-Warner Cable. To prevent this effect, the Commission ordered the two companies to make certain that "must have" programming (such as RSNs) would be available to competitors at non-discriminatory and reasonable market prices, as those prices would stand but for acquisition of the Adelphia systems. This is enforced by compulsory baseball-style arbitration.

The Commission's video access policy seems misguided. Whatever market power may be enjoyed by RSNs can only arise from their contracts with sports teams or leagues. Given the ease with which wholesale distributors (networks) of sporting events can enter and exit, as well as RSNs owned by teams themselves, the bulk of the rents from the business must accrue to the teams or leagues. If RSNs were not integrated with cable companies (a number aren't), they would demand equivalent terms from retail video distributors, including exclusivity if that is profit maximizing. Vertical integration, however, has the potential to increase welfare by various means, such as eliminating double marginalization. Perhaps more important, multichannel video distribution and Internet access in no longer a monopoly of cable systems. Satellites provide video competition, and telephone companies offer Internet access competition (and in some cases also video). The growing capacity and speed of wireless " $3 \mathrm{G}$ " and especially " $4 \mathrm{G}$ " mobile device networks will offer competition on both fronts. It is now possible to watch some professional-quality video entertainment on portable computers as well as desktop computers. An iPad, for example, can receive and exhibit online video programming even on a $3 \mathrm{G}$ network. The most effective policy, based on past experience with such interventions, would be to ensure that wireless providers have sufficient spectrum to offer effective competition to the wireline and satellite incumbents. There is no reason, aside from regulatory constraints on uses of available spectrum, to suppose that broadband distribution is any species of natural monopoly. If the industry should become a monopoly, it is policymakers themselves, not market failure, that will make it so.

Although the FCC leadership has made gestures toward repurposing some broadcast spectrum for wireless use, it has so far focused on unlicensed uses, which are not likely to be helpful (Hazlett 2010). The present Commission, as described above, has shown much stronger interest in a version of "net neutrality" that would impose common carrier access obligations not only on video distributors but also on local Internet Service Providers (ISPs) and perhaps on content providers that are affiliated with ISPs. ${ }^{22}$ Common carrier access schemes are often used in public utility or natural monopoly contexts, which overlap with cases of vertical integration that involve firms with market power. The Commission's position is that net neutrality is required to "preserve" the openness and creativity of the Internet (Nocera 2010). Critics respond that, so long as the Internet is and remains open and innovative there is little need for regulation. (Id.) The Adelphia framework most likely provides a glimpse of what net neutrality would mean in practice if adopted by the FCC, except that it would apply to all video programming and all Internet access services that are provided by cable or telephone companies.

\footnotetext{
$\overline{22}$ Schuett (2010) reviews economic work on net neutrality.
} 


\section{Conclusion}

The organization of production is always vertically integrated to some degree, and responsive to environmental pressures. There is no reason to single out the most recent change in structure as inherently suspicious from an antitrust perspective. Distinctions between "firms" and "markets" are artificial legal or taxonomic conveniences. Production takes place on account of agent relationships that span a multidimensional spectrum, of which one dimension ranges from fiat-like to market-like. An exclusive focus on fiat-like organizations is likely to miss a great deal of significant economic activity. Vertical integration by fiat-like organizations is much more likely to be an efficiency-enhancing reaction to environmental stress than to portend harm to competition and consumers. Section 2 of the Sherman Act is available for the exceptions. Toadying to uninformed populist fears of vertical integration between network providers and content creators by imposing investment-dampening ex ante regulatory constraints is likely to be far less useful to the public than are steps to ensure effective competition among network providers.

Acknowledgments The paper has benefitted from useful comments from Thomas Lenard, Greg Rosston, Michael Salinger, Carl Shapiro and Scott Wallsten.

Open Access This article is distributed under the terms of the Creative Commons Attribution Noncommercial License which permits any noncommercial use, distribution, and reproduction in any medium, provided the original author(s) and source are credited.

\section{References}

Acemoglu, D., \& Cao, D. V. (2010). Innovation by entrants and incumbents. NBER working paper 16411. September.

[Adelphia 2006] See FCC (2006).

Arrow, K. J. (1962). Economic welfare and the allocation of resources for invention. In M. G. Harold (Ed.) Chairman, Universities-National Bureau Committee for economic research, 1962. The rate and direction of inventive activity: Economic and social factors, Cambridge MA: NBER books, National Bureau of economic research, Inc.

Baker, J. B. (2007). Beyond Schumpeter vs arrow: How antitrust fosters innovation. Antitrust Law Journal, 74(3), 575-602.

Brown Shoe v. United States. (1962). 370 U.S. 294, 323-334.

Burt, D. L., \& Lemley, M. A. (2009). The patent crisis and how the courts can solve it. Chicago: University Chicago Press.

Bustos, A. E., \& Galetovic, A. (2009). Vertical integration and sabotage with a regulated bottleneck monopoly. The B.E. Journal of Economic Analysis \& Policy Issue 1 Article 35.

Buttrick, J. (1952). The inside contract system. The Journal of Economic History, 12(3), 205-221.

Coase, R. (1937). The nature of the firm. Economica, 4(16), 386-405.

Cooper, J. C., Froeb, L. M., O’Brien, D., \& Vita, M. G. (2005). Vertical antitrust policy as a problem of inference. International Journal of Industrial Organization, 23(7-8), 639-664.

Diamond, P. \& Vartiainen, H. (Eds.). (2007). Behavioral economics and its applications. Princeton: Princeton University Press.

Dutton, H. I., \& Jones, S. R. H. (1983). Invention and innovation in the British pin industry, 1790-1850. Business History Review, 62, 175-193.

Eastman Kodak Co. v. (1992). Image technical services Inc., 504 U.S. 451.

Englander, E. J. (1987). The inside contract system of production and organization: A neglected aspect of the history of the firm. Labor History, 28, 4429-4446. 
Evans, D. S., \& Schmalensee, R. (2002). Some economic aspects of antitrust analysis in dynamically competitive industries, In Innovation policy and the economy 2 (pp. 1-50). Cambridge: National Bureau of Economic Research Inc.

FCC. (2006). [Adelphia] In the matter of applications for consent to the assignment and/or transfer of control of licenses, MB Docket No. 05-192. Memorandum opinion and order, released July 21, 2006. FCC 06-105.

FCC. (2010). Open internet order. FCC No. 10-201 (rel. Dec. 23, 2010).

Fellner, W. (1951). The influence of market structure on technological progress. The Quarterly Journal of Economics, 65, 556-577.

Feng, L., \& Hendrikse, G. (2010). Cognition and governance structure. Working paper. University of Rotterdam. Presented at workshop on valuation methods in agro-food and environmental economics, Barcelona, July 1, 2010. http://www.creda.es/Web\%20workshop\%202010/full\%20papers/Feng.pdf.

Gibbons, R. (2010). Inside organizations: Pricing, politics, and path dependence. Annual Review of Economics, 2, 337-365.

Goldfine, D. A. J., \& Vorrasi, K. M. (2004). The fall of the Kodak aftermarket doctrine: Dying a slow death in the lower courts. Antitrust Law Journal, 72(1), 209-231.

Hahn, R., \& Passel, P. (2010). Greasy pole economics. regulation2pointO (August 19) http:// regulation2point0.org/.

Hart, O., \& Holmstrom, B. (2010). A theory of firm scope. Quarterly Journal of Economics, 125(2), 483-513.

Hazlett, T. W. (2010). Shooting blanks on wireless policy. Financial times FT.com. October 5.

Holmes, O. W., Jr. (1897). The path of the law. Harvard Law Review, 10, 457.

Holmstrom, B., \& Roberts, J. (1998). The boundaries of the firm revisited. Journal of Economic Perspectives, 2, 73-94.

Jackson, C. K., \& Schneider, H. S. (2010). Do social connections reduce moral hazard? Evidence from the New York City taxi industry. NBER working paper 16279.

Joskow, P. L. (2005). Vertical integration. In Handbook of new institutional economics, Ch. 13 (pp. 319-348). Kluwer handbook of new institutional economics 2005, Section 4.

Kahn, A. E. (1988). The economics of regulation: Principles and institutions. Cambridge: MIT Press.

Klein, B., Crawford, R. G., \& Alchian, A. A. (1978). Vertical integration, appropriable rents, and the competitive contracting process. Journal of Law and Economics, 21(2), 297-326.

Kodak. (1992). See Eastman Kodak Co. v. Image Technical Services Inc.

Lafontaine, F., \& Slade, M. (2007). Vertical integration and firm boundaries: The evidence. Journal of Economic Literature, XLV, 629-685.

Lafontaine, F., \& Slade, M. (2008a). Inter-Firm contracts: Evidence. Forthcoming in Gibbons \& Roberts (eds) Working Paper. Handbook of organizational economics, Princeton University Press 2012.

Lafontaine, F., \& Slade, M. E. (2008b). Exclusive contracts and vertical restraints: Empirical evidence and public policy. In B. Paolo (Ed.), Handbook of antitrust economics (pp. 391-414). Cambridge: MIT Press.

Lee, J. S. (2010a). The functions and fortunes of English small towns at the close of the middle ages: Evidence from John Leland's itinerary. Urban History, 37, 1-25.

Lee, R. S. (2010b). Vertical integration and exclusivity in platform and two-sided markets. Working paper. Stern School of Business, New York University. http://pages.stern.nyu.edu/ rslee/papers/ VIExclusivity.pdf.

Lemley, M. A. (2010). Industry-specific antitrust policy for innovation. Working paper. Stanford Law School. http://ssrn.com/abstract=1670197

Lyons, B. R. (1996). Empirical relevance of efficient contract theory: Inter-firm contracts. Oxford Review of Economic Policy, 12(4), 27-52.

Microsoft. (2002). See United States v. Microsoft Corp.

Nocera, J. (2010). The struggle for what we already have. New York Times. September 3. http://www. nytimes.com/2010/09/04/business/04nocera.html?_r=1\&pagewanted=print.

Noll, R. G., \& Owen, B. M. (1994). United States v. AT\&T: The Economic Issues. In J. Kwoka \& L. White (Eds.) The antitrust revolution 2nd edn. Scott Foresman 1988.

Ordover, J. A., Saloner, G., \& Salop, S. (1990). Equilibrium vertical foreclosure. American Economic Review, 80, 127-142.

Organization for economic co-operation and development (OECD). (1993). Technology diffusion: Tracing the flows of embodied R\&D in eight OECD countries. DSTI/EAS (93):5 Rev.1. Paris. 
Owen, B. M. (2007). Antecedents to net neutrality. Regulation Fall 14.

Posner, R. A. (2000). Antitrust in the new economy. Antitrust Law Journal, 68, 925-943.

Pratten, C. F. (1980). The manufacture of pins. Journal of Economic Literature, XVIII, 93-96.

Rhodes-Kropf, M., \& Robinson, D. T. (2008). The market for mergers and the boundaries of the firm. Journal of Finance, 63(3), 1169-1211.

Riordan, M., \& Salop, S. (1995). Evaluating vertical mergers: A post-Chicago approach. Antitrust Law Journal, 63, 513-568.

Riordan, M. H. (2008). Competitive effects of vertical integration. In B. Paolo, Handbook of antitrust economics. Cambridge: MIT Press.

Robinson, D. T. (2008). Strategic alliances and the boundaries of the firm. The Review of Financial Studies, 21(2), 649-681.

Salinger, M. A. (1988). Vertical mergers and market foreclosure. Quarterly Journal of Economics, $103,345-356$.

Salop, S. C., \& Scheffman, D. T. (1987). Cost-raising strategies. Journal of Industrial Economics, 36(1), 19-34.

Schmalensee, R. (1992). Sunk cost and market structure: A review article. Journal of Industrial Economics, 40, 125-134.

Schmalensee, R. (2000). Antitrust issues in Schumpeterian industries. The American Economic Review. 90(2):192-196. In Papers and proceedings of the 112th annual meeting of the American Economic Association (May, 2000).

Schmalensee, R. \& Willig, R. D. (Eds.). (1989). The handbook of industrial organization. North Holland: Elsevier .

Schuett, F. (2010). Network neutrality: A survey of the economic literature. Review of Network Economics. 9(2):1 http://www.bepress.com/rne/vol9/iss $2 / 1$.

Schumpeter, J. (1950). Capitalism, socialism and democracy (3rd ed.). New York: Harper.

Smith, A. (1776). An inquiry into the nature and causes of the wealth of nations, 2 Vols., Everyman's library. London: Dent \& Sons 1904.

Stewart, P. (1966). Dissent in United States v. Von's Grocery. 384 U.S., 270, 281.

Stigler, G. J. (1951). The division of labor is limited by the extent of the market. Journal of Political Economy, 59, 185-193.

Sutton, J. (1991). Sunk costs and market structure. Cambridge: MIT Press.

Swan, P. (1970). Market structure and technological progress: The influence of monopoly on product innovation. The Quarterly Journal of Economics, 84, 627-638.

Teece, D. J. (1992). Competition, cooperation, and innovation: Organizational arrangements for regimes of rapid technological progress. Journal of Economic Behavior and Organization, 18, 1-25.

Trinko. (2004). see Verizon Communications Inc. v. Law Offices of Curtis V. Trinko.

United States Antitrust Modernization Commission. (2007). Report and Recommendations. http://govinfo. library.unt.edu/amc/report_recommendation/amc_final_report.pdf.

U.S. Department of Justice-Federal Trade Commission Horizontal Merger Guidelines (rev. 2010) http:// www.ftc.gov/os/2010/08/100819hmg.pdf

United States v. Microsoft Corp. (2002). 253 F.3d 34 (D.C. Cir. 2001) (en banc); Final Judgment No. 98-1232, 2002 WL 31654530 (D.D.C. Nov. 12, 2002)).

United States v. Von's Grocery. (1966). 384 U. S. 270, 281.

Varian, H. R. (2001). High technology industries and market structure. Working paper, University of California at Berkeley. http://people.ischool.berkeley.edu/ hal/Papers/structure

Verizon Communications Inc. v. Law Offices of Curtis V. Trinko, 540 U. S. 398 (2004). [Trinko 2004].

Williamson, O. E. (1975). Markets and hierarchies: Analysis and antitrust implications. New York: Free Press.

Williamson, O. E. (1985). The economic institutions of capitalism. New York: Free Press.

Williamson, O. E. (1991). Comparative economic organization: The analysis of discrete structural alternatives. Administrative Science Quarterly, 36(2), 269-296.

Williamson, O. E. (1996). The mechanisms of governance. Oxford, UK: Oxford University Press.

Yoo, C. S. (2002). Vertical integration and media regulation in the new economy. Yale Journal on Regulation, 19, 171.

Zanarone, G. (2009). Vertical Restraints and the Law: Evidence from automobile franchising. Journal of Law and Economics, 52, 691. 